\title{
Revisiting the 'cornerstone of Amazonian conservation': a socioecological assessment of Brazil nut exploitation
}

\author{
Manuel R. Guariguata ${ }^{1}$ Peter Cronkleton' ${ }^{1}$ Amy E. Duchelle ${ }^{2}$ • \\ Pieter A. Zuidema ${ }^{3}$
}

Received: 23 September 2016/Revised: 31 March 2017/Accepted: 18 April 2017/

Published online: 22 April 2017

(C) The Author(s) 2017. This article is an open access publication

\begin{abstract}
The Brazil nut (the seeds of the rainforest tree Bertholletia excelsa) is the only globally traded seed collected from the wild by forest-based harvesters across the Amazon basin. The large geographic scale of Brazil nut exploitation and the significant contributions to local livelihoods, national economies, and forest-based development over the last decades, merit a review of the "conservation-through-use" paradigm. We use Elinor Ostrom's framework for assessing sustainability in socioecological systems: (1) resource unit, (2) users, (3) governance system, and (4) resource system, to determine how different contexts and external developments generate specific conservation and development outcomes. We find that the resource unit reacts robustly to the type and level of extraction currently practiced; that resource users have built on a self-organized system that had defined boundaries and access to the resource; that linked production chains, market networks and informal financing work to supply global markets; and that local harvesters have used supporting alliances with NGOs and conservationists to formalize and secure their endogenous governance system and make it more equitable. As a result, the Brazil nut model represents a socioecological system that may not require major changes to sustain productivity. Yet since long-term Brazil nut production seems inextricably tied to a continuous forest cover, and because planted Brazil nut trees currently provide a minimal contribution to total nut production basin-wide, we call to preserve, diversify and intensify production in Brazil nut-rich forests that will inevitably become ever more integrated within human-modified landscapes over time.
\end{abstract}

Communicated by Daniel Sanchez Mata.

Manuel R. Guariguata

m.guariguata@cgiar.org

1 Center for International Forestry Research, Lima, Peru

2 Center for International Forestry Research, Bogor, Indonesia

3 Forest Ecology and Forest Management, Wageningen University, Wageningen, The Netherlands 
Keywords Amazonia - Deforestation - Forest conservation - Tropical forest $\cdot$ Local livelihoods · Non-timber forest products

\section{Introduction}

One of the oddities of the NTFP category is that it excludes both the most structurally important components of the forest, and the ecological functions that bind it together (Lawrence 2003).

Non-timber forest products (NTFPs) are harvested across the tropics from diverse habitats and management systems, from cultivation on farms to wild harvest in forests. NTFPs reach both international and domestic markets and supply millions of rural households with significant income for their subsistence (Angelsen et al. 2014; Shanley et al. 2016). NTFPs gained prominence in the global forest agenda with the 1992 Rio Forest Principles, which promoted an integrated approach to livelihoods, the environment and forest management for a tropical forestry sector dominated by an industrial timber model (Rosendal 1995). An exemplary tropical NTFP is the Brazil nut (from the seeds of the Amazon rainforest tree Bertholletia excelsa). Over the last few decades, the harvesting of Brazil nuts has been a key resource, supporting the "conservation-through-use" of millions of hectares of Amazonian forest by tens of thousands of rural households (Ortiz 2002) and is an integral component of the extractivist culture of many indigenous and local communities (Clay and Clement 1993; Table 1). The large geographic scale of exploitation (Peres et al. 2003) and the significant contributions to local livelihoods and forest-based development prompted researchers to call the Brazil nut the cornerstone of Amazon forest conservation (Clay 1997). At present, the Brazil nut is the only globally traded seed crop collected from the wild by forest-based harvesters. Brazil nut extraction generates tens of millions of US dollars in annual export value in Brazil, Peru and Bolivia (Coslovsky 2014), the three countries which constitute the focus of this assessment.

In this paper, we reassess the role that Brazil nut extraction plays in Amazon rainforest conservation and evaluate the socioecological system of Brazil nut extraction to try to discern under which settings the "conservation-through-use" paradigm is applicable for this exemplary Amazonian tree in a changing environment. Since resource ecology and extraction are closely linked to socioeconomic development, we structure our review by adapting Ostrom's (2009) framework for assessing sustainability in socioecological systems into four subsystems: (1) resource unit (i.e., the Brazil nut tree), (2) users (e.g., harvesters, middlemen, processors), (3) governance system (e.g., institutions, incentives, market and non-market instruments) and (4) resource system (i.e., Brazil nut-rich forests; defined here as those with at least $0.5-1$ adult Brazil nut tree per hectare). We have chosen this structure because forests are an emblematic example of common-pool resources (Ostrom 1990), and Brazil nut production systems offer an illustrative case where a variety of stakeholders have self-organized to allocate property rights and to develop adaptable market networks that have persisted for the better part of a century (Ortiz 2002). In our assessment, we examine how different interventions and external developments both affect and interact across the four subsystems mentioned above, all of which generate specific conservation and development outcomes along with feedback loops. The wealth of information produced over recent years on this regionally prominent NTFP (its 
Table 1 The percentage of total forest income derived from harvesting of Brazil nuts in selected Amazonian sites, from recently published literature

\begin{tabular}{|c|c|c|c|c|c|}
\hline $\begin{array}{l}\text { Location } \\
\text { (country) }\end{array}$ & $\begin{array}{l}\% \text { of total } \\
\text { household income } \\
\text { from forest } \\
\text { products }\end{array}$ & $\begin{array}{l}\% \text { of forest } \\
\text { income derived } \\
\text { from Brazil nuts }\end{array}$ & Sample type & Land use type & Source \\
\hline $\begin{array}{l}\text { Pando, } \\
\text { Beni } \\
\text { (Bolivia) }\end{array}$ & 42 & 22 & 239 households & $\begin{array}{l}\text { Colonist } \\
\text { settlement }\end{array}$ & $\begin{array}{l}\text { Zenteno } \\
\text { et al. } \\
(2013)\end{array}$ \\
\hline $\begin{array}{l}\text { Pando, } \\
\text { Beni } \\
\text { (Bolivia) }\end{array}$ & 60 & 51 & $\begin{array}{l}\text { "Extractive" } \\
\text { communities } \\
\text { (27\% of } 239 \\
\text { households) }\end{array}$ & $\begin{array}{l}\text { Colonist } \\
\text { settlement }\end{array}$ & $\begin{array}{l}\text { Zenteno } \\
\text { et al. } \\
\text { (2013) }\end{array}$ \\
\hline $\begin{array}{l}\text { Pando, } \\
\text { Beni } \\
\text { (Bolivia) }\end{array}$ & 36 & 20 & $\begin{array}{l}\text { "Multitasking" } \\
\text { communities } \\
\text { (33\% of } 239 \\
\text { households) }\end{array}$ & $\begin{array}{l}\text { Colonist } \\
\text { settlement }\end{array}$ & $\begin{array}{l}\text { Zenteno } \\
\text { et al. } \\
\text { (2013) }\end{array}$ \\
\hline $\begin{array}{l}\text { Pando, } \\
\text { Beni } \\
\text { (Bolivia) }\end{array}$ & 53 & 27 & $\begin{array}{l}\text { Brazil nut and timber } \\
\text { extraction ( } 18 \% \text { of } \\
239 \text { households) }\end{array}$ & $\begin{array}{l}\text { Colonist } \\
\text { settlement }\end{array}$ & $\begin{array}{l}\text { Zenteno } \\
\text { et al. } \\
\text { (2013) }\end{array}$ \\
\hline $\begin{array}{l}\text { Pando } \\
\text { (Bolivia) }\end{array}$ & 64 & 45 & 131 households & $\begin{array}{l}\text { Protected area, } \\
\text { nonprotected } \\
\text { area }\end{array}$ & $\begin{array}{l}\text { Duchelle } \\
\text { et al. } \\
\text { (2014a) }\end{array}$ \\
\hline $\begin{array}{l}\text { Acre } \\
\text { (Brazil) }\end{array}$ & 12 & 21 & 112 households & $\begin{array}{l}\text { Extractive } \\
\text { reserve, } \\
\text { colonist } \\
\text { settlements }\end{array}$ & $\begin{array}{l}\text { Duchelle } \\
\text { et al. } \\
\text { (2014a) }\end{array}$ \\
\hline $\begin{array}{l}\text { Pará } \\
\text { (Brazil) }\end{array}$ & 33 & 17 & 23 households & $\begin{array}{l}\text { Extractive } \\
\text { reserve }\end{array}$ & $\begin{array}{l}\text { Zeidemann } \\
\text { et al. } \\
\text { (2014) }\end{array}$ \\
\hline $\begin{array}{l}\text { Madre de } \\
\text { Dios } \\
\text { (Peru) }\end{array}$ & 71 & $55-65$ & 126 households & $\begin{array}{l}\text { Brazil nut } \\
\text { concessions }\end{array}$ & $\begin{array}{l}\text { Garrish } \\
\text { et al. } \\
\text { (2014) }\end{array}$ \\
\hline $\begin{array}{l}\text { Pando, } \\
\text { Beni } \\
\text { (Bolivia) }\end{array}$ & 59 & 74 & $\begin{array}{l}24 \text { households } \\
\text { "Agroextractive } \\
\text { communities" }\end{array}$ & $\begin{array}{l}\text { Colonist } \\
\text { settlement }\end{array}$ & $\begin{array}{l}\text { Soriano } \\
\text { et al. } \\
(2017)\end{array}$ \\
\hline
\end{tabular}

geographical distribution shown in Fig. 1) provides an opportunity to offer a nuanced view on the biophysical, socioeconomic, institutional and governance aspects influencing the resource base in light of the current transformation of the Amazonian forest landscape (de Jong et al. 2010). Our review provides input to answer the following question: what set of key interventions may be needed to maintain the social, economic and environmental functions of Brazil nut-rich forests?

\section{The resource unit}

Brazil nut trees can live for hundreds of years (Brienen and Zuidema 2006; Schöngart et al. 2015), attain heights of over $40 \mathrm{~m}$ (Mori and Prance 1990) and reach diameters (at breast height, Fig. 2a) of up to $5 \mathrm{~m}$ (de Salomão 1991; Peres et al. 2003; Brienen and Zuidema 2006; Kainer et al. 2007; Rockwell et al. 2015). They form high density groves (up to 


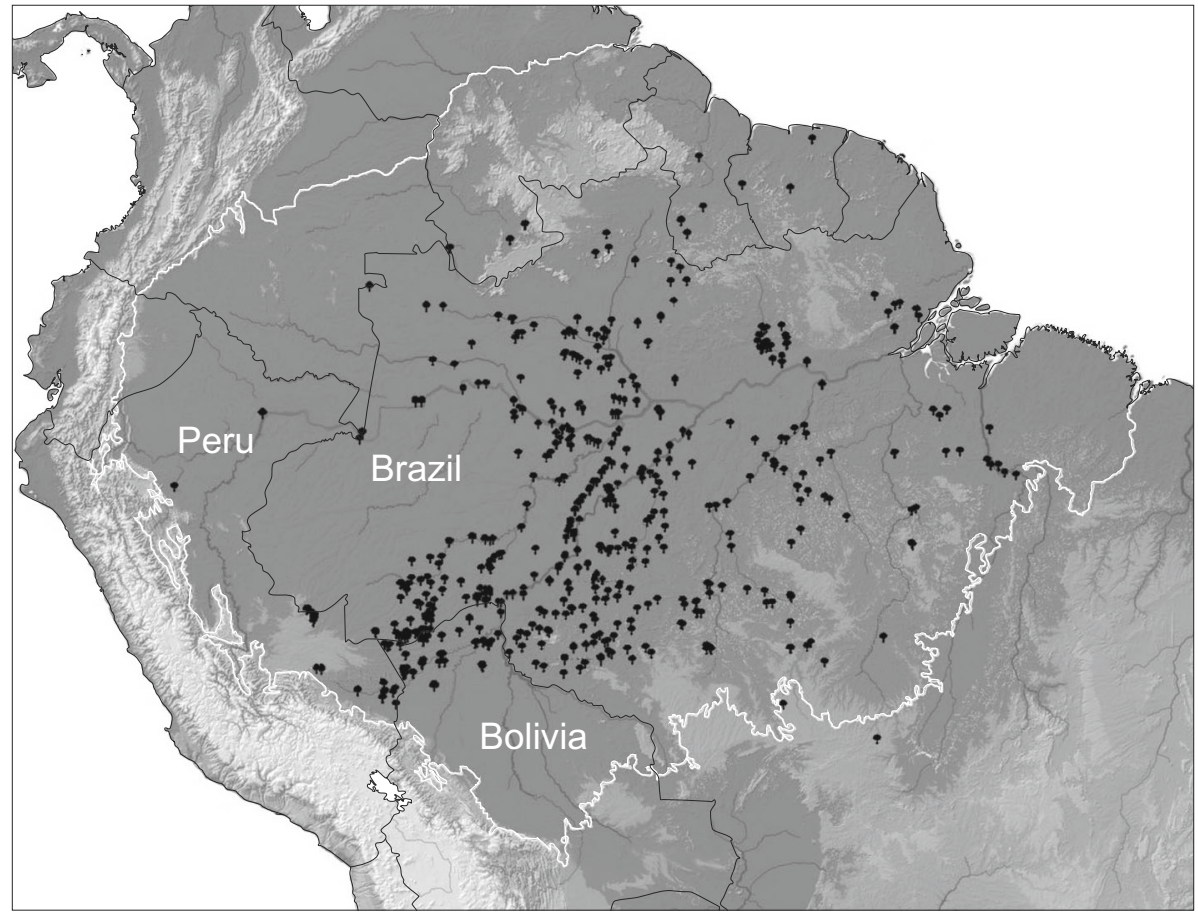

Fig. 1 The distribution of Brazil nut trees (Bertholletia excelsa) as evidenced by botanical records across the Amazon river basin (delineated in white). Modified from Clement et al. (2015)

15-20 adult individuals per ha; Mori and Prance 1990) probably due to the combined effects of anthropogenic activities (Shepard and Ramirez 2011; Scoles and Gribel 2012; Thomas et al. 2015) and short-distance seed dispersal by rodents (Peres and Baider 1997; Haugaasen et al. 2012). Cross-pollination (mediated primarily by non-social bees of the genus Xylocopa; Cavalcante et al. 2012) is necessary for fruit production and generates high levels of genetic diversity and low levels of inbreeding (Sujii et al. 2015). The seeds are contained within a globose, woody fruit (Fig. 2b, c).

It has been long hypothesized that a forested matrix (for hosting pollinators) is necessary for sustaining commercial Brazil nut yields and, therefore, that forest fragmentation and degradation could reduce tree fecundity (Ortiz 2002). Yet at present it is not known under which landscape configurations fruit yields are to decrease via potential disruption of inter-tree pollen transfer. In any case, at low timber harvesting intensities in closed-canopy forest, Brazil nut tree fecundity seems unaffected (Rockwell et al. 2015). Although promising efforts to intensify Brazil nut production through plantations do exist most prominently in central Brazil, yields are low (probably related to the specialized nature of their pollinators and type of planting material) thus making both market and volume shares currently insignificant basin-wide (Homma et al. 2014).

Current evidence suggests that the regeneration potential via seedlings and saplings of Brazil nut tree populations appears uncorrelated to the intensity of fruit harvest (Wadt et al. 2008; Scoles and Gribel 2012, 2015), although some areas that have experienced long and intensive harvesting pressure show evidence of a "demographic bottleneck" (i.e., absence of pre-reproductive trees; Peres et al. 2003). Yet if seed collection would cause 

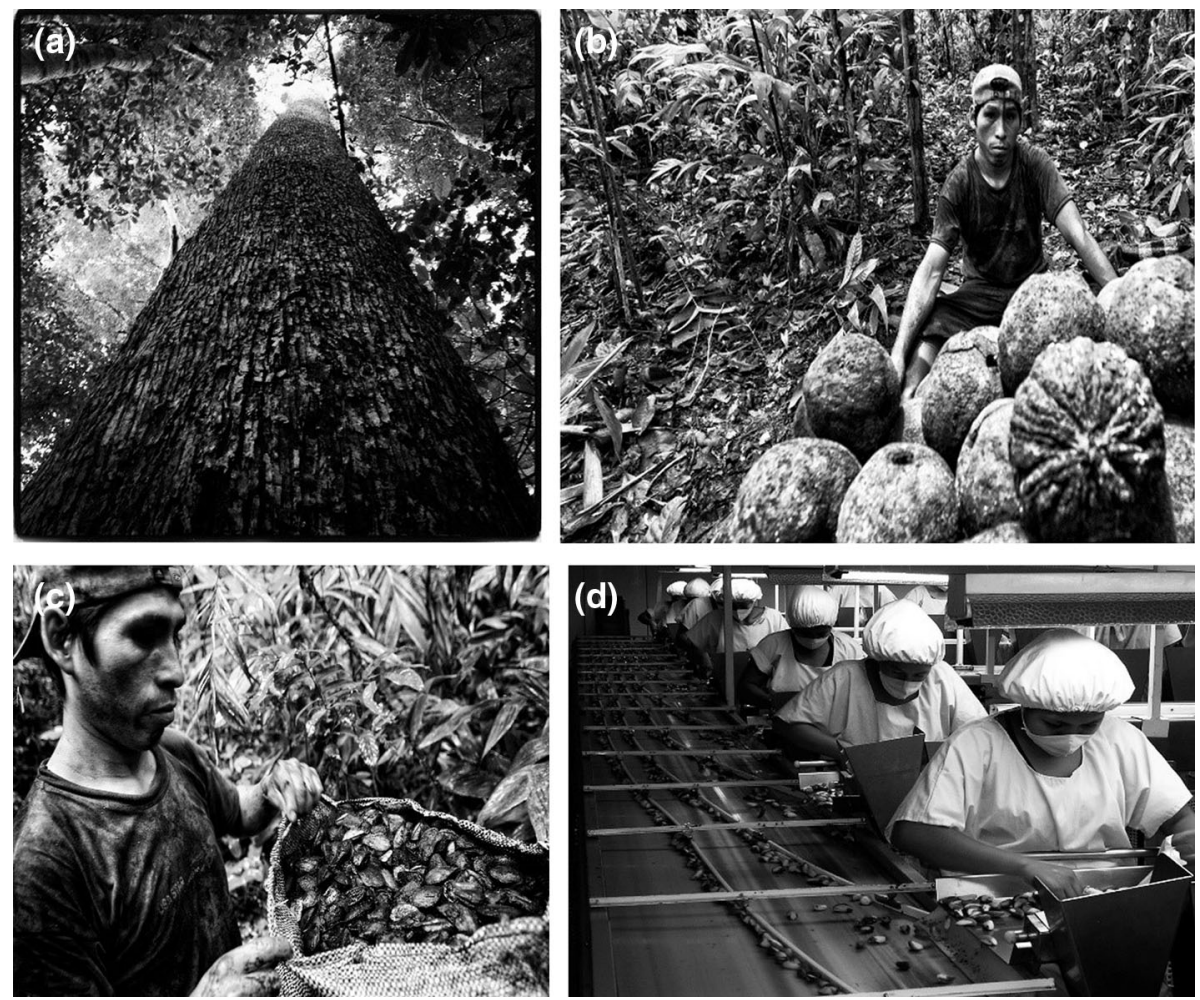

Fig. 2 Graphic depiction of two out of the four subsystems that comprise the Brazil nut socioecological system (after Ostrom 2009). The "resource unit" (a) is the Brazil nut tree (individual shown is about $1.5 \mathrm{~m}$ in diameter at breast height and about $30 \mathrm{~m}$ tall; Madre de Dios, Peru). "Resource users" include harvesters (b, c; Madre de Dios, Peru), middlemen, and industry (d; Pando, Bolivia). Not shown (yet described in the text) are the "governance system" (i.e., institutions, rules and incentives) and the "resource system" (i.e. Brazil nut-rich forests)

regeneration bottlenecks, it would take several decades and probably up to a century to cause decline in Brazil nut productivity (Zuidema and Boot 2002). The abundance of naturally-regenerated, pre-reproductive Brazil nut trees is very low in shaded forest understories (Mori and Prance 1990; Myers et al. 2000; Rockwell et al. 2017) but high abundances are reported in young logging gaps (Soriano et al. 2012) and agricultural fallows close to old-growth forest (Cotta et al. 2008; Paiva et al. 2011). Seed harvesting is exclusively limited to collecting the fruits that fall to the ground during the rainy months, and opening them with a machete. Harvesting may extend beyond the end of the rainy season when export demand is very high, as happens in Bolivia (Duchelle et al. 2011).

\section{The resource users}

The constellation of stakeholders that make up the Brazil nut sector participate in a production system that has extracted forest products for global markets since at least the seventeenth century while recent patterns and organizational systems are more closely rooted to the late nineteenth century extractive boom of wild rubber (Hevea brasiliensis). 
Key aspects of that economic system for the extraction and global trade of wild NTFPs have persisted (Laird et al. 2010) yet shifting economic cycles and contested development trajectories have introduced new modes of control over the Brazil nut resource base. For example, although the harvesting of Brazil nuts has been catalogued as a "specialized natural strategy" (Belcher et al. 2005) optimizing both development and conservation outcomes (Kusters et al. 2006), and the activity has been characterized as one with a "high potential" for conservation-through-use (Newton 2008), these categorizations hide the large variation in socioecological and policy contexts across the Amazon basin (de Jong et al. 2010). Brazil nut resource users are spread across different tenure types: indigenous reserves (Ribeiro et al. 2014), extractive reserves (Zeidemann et al. 2014) and other government-sanctioned protected areas (Duchelle et al. 2014a), along with governmentsanctioned concessions (Cossio-Solano et al. 2011), as well as communal and individual private property (Cronkleton and Pacheco 2010; Zenteno et al. 2013; Soriano et al. 2017).

As mentioned, the foundation of the Brazil nut economy emerged in the second half of the nineteenth century as early entrepreneurs moved across the Amazon to establish large forest estates to extract rubber (referred to as seringais in Portuguese and barracas or fundos in Spanish; Fifer 1970; Weinstein 1983; Coomes and Barham 1994). From the colonial period, estate owners in the Amazon had depended on coerced labor from indigenous people, but as the rubber boom accelerated, labor shortages required that they bring indentured workers from outside the region to settle in forests and extract rubber latex for global markets. During the boom, estate owners used debt peonage to control these workers, but as the rubber economy collapsed, the workers gained more autonomy and began exerting customary control over forest resources (Weinstein 1983; Bakx 1988; Ormachea and Fernández 1989; Pacheco 1992; Barham and Coomes 1996). While the estate owners maintained property claims, the forest workers expanded their livelihoods beyond rubber tapping and began extracting a wider range of forest products, particularly the Brazil nut. In Bolivia, for example, the Brazil nut had eclipsed rubber as the principal non-timber forest product by the 1950s (Stoian and Henkemans 2000).

As the economy changed, the forest estates provided external boundaries, which allowed resident extractivist populations to develop management institutions over these essentially common-pool resources. Within these properties, producers claimed customary private access to Brazil nut groves based on a form of 'tree tenure' (Fortmann 1985) in which individual families control economically valuable trees rather than the land itself. However, from the 1970s onward, economic change and shifts in development policies in each of the three countries further undercut the power of former estate owners and brought increased resource competition, thereby provoking social conflict and grassroots collective action in some cases. The conflict and unrest eventually pushed governments to introduce new property or resource access mechanisms that consolidated local control over the resource system. We briefly summarize below key parallels and differences as to how these changes played out in Brazil, Peru and Bolivia.

In Brazil, changing development incentives during the 1970s and 1980s encouraged forest estate owners to sell property claims (often to cattle ranchers), which sparked collective resistance by forest peoples (Schmink and Wood 1992). Rubber tappers, many of whom were also dependent on Brazil nut extraction, began forming a grassroots movement with assistance from the Catholic Church and environmental, non-governmental organizations (NGOs) (Schmink and Wood 1992; Assies 1997a), to pressure the government to recognize new property types, including conservation areas called extractive reserves (Allegretti 1990) and agro-extractive settlements (Cronkleton et al. 2008), both of which were communal areas intended to support customary livelihoods and patterns of forest use. 
In Bolivia, barraca estate owners were not initially affected by waves of agrarian reform, but later had their rights challenged when the government granted logging contracts over extensive areas of Brazil nut production forests in 1995 (Pacheco 1998) and eventually converted these into timber concessions under the 1996 Forestry Law. In 2000, while the estate owners (barraqueros) lobbied the government to reestablish their control over remaining Brazil nut-rich forests, resistance from a coalition of Brazil nut gatherers supported by NGOs pressured the government to instead issue a series of presidential decrees that recognized communal properties for Brazil nut-dependent communities (Cronkleton and Pacheco 2010).

Peru's 1969 agrarian reform invalidated remaining property claims of forest estate owners and the 1975 Forestry Law recognized the rights of rural producers to continue gathering Brazil nuts and rubber through extraction contracts. This contract system continued until Peru's 2000 Forestry Law mandated their replacement by forest concessions. Initially, there was some uncertainty over how concession rights would be granted (Congreso del Perú 2002), but after a period of protests by Brazil nut gatherers and NGOs, the government agreed to honor their acquired rights held under preexisting Brazil nut extraction contracts.

This devolution of forest property rights resulted in a large transfer of Brazil nut-rich forests to local control by resource users. In Bolivia's Pando department alone, by 2010, over two million hectares of forest had been titled to 132 communities and two indigenous territories (Cronkleton and Pacheco 2010), with the remainder held in timber concessions or still claimed by barraqueros. In Peru's department of Madre de Dios, as of 2015 there were 1174 Brazil nut concessions and 6 indigenous communities controlling approximately one million hectares of forested land (Perales and Guariguata 2015). In Brazil, the 2011 national plan for supporting community forest management of NTFPs (which prioritized Brazil nuts) identified 22 conservation units (including extractive reserves) and 15 agroextractive settlements covering more than 12 million hectares and almost 20,000 families (SFB 2010). While these shifts in property rights favored Brazil nut gatherer households, there are still large areas of Brazil nut-rich forests on private properties in Brazil and Bolivia, in timber concessions in Bolivia (Guariguata et al. 2009) and Peru (Chavez et al. 2012), and in public forest areas in all three countries. Given the overall (yet dynamic) importance of Brazil nut-rich forests as sources of a significant proportion of local household income (Table 1), it is crucial to understand how a mix of domestic policies, supply chains and incentives come together in Brazil, Peru and Bolivia, either to support or threaten the future of this socioecological system.

\section{The governance system}

\section{Policy frameworks}

The policy frameworks in each country establish co-management systems where government partially transferred rights over forest resources to local users, but retained key oversight authority. In co-management schemes, governments need to provide secure property rights that define who has rights and responsibilities to manage, and to establish guidelines or frameworks that encourage sustainable management practices (Cronkleton et al. 2012a). An important step in securing resource rights is apparent in the multiple types of property institutions created to grant to indigenous peoples and extractivist populations 
rights over Brazil nut-rich forests. In extractive reserves in Brazil, for example, the external reserve boundaries allowed the exclusion of outsiders but accommodated the residents' forest-based livelihoods by tacitly recognizing existing customary patterns of resource access and internal control (Ankersen and Barnes 2004). In contrast, in Pando, Bolivia, the formalization of customary rights through the government's 500-ha-per-family decree created confusion in the sense that local norms and rules for managing Brazil nut-rich forests would be rearranged internally (Cronkleton et al. 2010). Such differences in the process of formally recognizing customary rights can have implications for resource management, as evidenced by an increase in conflicts over Brazil nuts in Pando (that did not happen across the border in Acre, Brazil) when nut prices increased (Duchelle et al. 2011).

Policy makers in all three countries have taken legal steps to conserve the Brazil nut resource base. Peru's government banned the felling or burning of Brazil nut trees in 1981 and in 1997 prohibited the titling of lands with Brazil nut trees (Cossio-Solano et al. 2011). The original Brazilian Forest Code of 1965, along with subsequent legislation banned the cutting of Brazil nut trees (Homma 2001). Bolivia, on the other hand, did not prohibit the felling of Brazil nut trees until 2004 (Cronkleton and Pacheco 2010). Although these policies have largely stopped the exploitation of Brazil nut trees for timber, they do not guarantee the conservation of surrounding forest. "Brazil nut cemeteries", where standing Brazil nut trees in pastures are either dead or hardly set any fruit, perhaps due to fire damage and reproductive isolation from conspecific individuals, are common across deforested Amazonian landscapes (Silva Bentes et al. 1988; Peña 2010).

In Peru, with the creation of the Brazil nut concession system in 2000, the government established the most elaborate administrative compliance systems for Brazil nut harvesting and transport of the three countries examined here. As mentioned, Brazil nut gatherers who held harvest contracts prior to 2000 were required to document their preexisting rights to qualify for a concession and then needed to work with forestry professionals to develop management plans to gain approval. Once approved, the technical norms require concession holders to prepare annual operating plans that estimate the total volume of seeds to be harvested a priori. Yet due to strong inter-annual variation in fruit production at the tree level (Kainer et al. 2007), it is virtually impossible to predict harvestable yields (essential information for approving operating plans). While the administrative and financial burden of these requirements for complying with these regulations are high, the information these plans provide for supporting management decisions at the concessionaire and central government levels is of little use (Perales and Guariguata 2015).

In Bolivia, the technical norms for timber management under the 1996 Forestry Law allowed the inclusion of Brazil nut harvesting (MDS 1998). However, the requirements were vague and thus generally ignored (Cronkleton et al. 2012b). In 2005, while Bolivia ratified technical norms only for Brazil nut management (MDS 2005), these were modeled on timber harvesting plans rather than specifically addressing the management behavior of Brazil nut extractors. The norms required the delineation of a 'no-take' zone intended to enhance Brazil nut regeneration via seed germination (which would add substantial opportunity costs to harvesters and also likely to be ineffective, as Brazil nut tree establishment is severely limited under a closed canopy as mentioned above). Governmentsanctioned, Brazil nut 'management' plans prepared under these norms have also been disregarded and have had little impact on changing the status quo (Cronkleton et al. 2012b). 


\section{Supply chains, cooperatives and certification}

While the Brazil nut sector has been tied to global markets from its inception, the role played by different stakeholders in the supply chain has evolved over time. The Brazil nut value chain originates with nut gatherers who, during the harvest season, live in rural homesteads linked to trails leading to the Brazil nut trees where they collect the fruits from the forest floor. With the recognition of forest property rights, many of these families have gained more autonomy through managing the resources they control, often within communal properties, or with individual rights as in Peruvian Brazil nut concessions. In the remaining large tracts of Brazil nut-rich forest claimed as private property or granted as timber concessions, contract labor is still used. For such cases, substantial numbers of families continue to supply migrant labor (especially in Bolivia). Although machinery to shell Brazil nuts was brought to the Amazon in the early twentieth century (Fifer 1970), it was not until the 1990s that processing plants became more prominent, particularly in Bolivia (Fig. 2d; Cronkleton and Pacheco 2010). The export market of shelled nuts began in the Brazilian municipality of Marabá in the state of Pará in the Eastern Amazon, and was dominated for decades by the oligarchic Mutran family in the mid-1900s. In 1998, European importers raised their quality standards for Brazil nuts and Brazilian exporters' access to the European market was impeded (Newing and Harrop 2000; Coslovsky 2014). Other reasons given for the decline of Brazil nut production in Brazil include less productive trees in the Eastern Amazon, deficient infrastructure for transport and storage, and the lack of policies and programs to incentivize production (Toledo et al. 2016). In Bolivia, processing industries, with support from government regulators effectively met food safety standards and did not lose access to the important European markets (Cronkleton and Pacheco 2010). At present, Bolivia dominates the global Brazil nut processing and export market (Coslovsky 2014). As of 2013, Bolivia produced $52 \%$, Brazil $42 \%$ and Peru $6 \%$, according to FAOSTAT (http://www.fao.org/faostat/en/\#home). ${ }^{1}$

Historically, gatherers used nuts to repay the estate owner for incurred debts; however, today's autonomous gatherers deal with competing intermediaries who are attempting to secure nuts for resale and processing. With more secure property rights, competition among buyers and higher prices, gatherers now have more leverage in negotiating terms of sale than in the past. Many processing plants establish trade networks, extending credit to secure access to sufficient supply to fulfill their contracts with international buyers. As Brazil nut gatherers in the region were struggling to defend their rights to forests and gain a higher profile, a common strategy of NGOs and bilateral donors was to support the formation of cooperatives and in some cases assist them to establish producer-owned processing plants. In Acre, Brazil, the rubber tapper's union set up Cooperativa Agro-extrativista de Xapuri (CAEX) in 1988 (Assies 1997b), and in Bolivia, the producer-owned Cooperativa Agrícola Integral Campesino Ltda (CAIC) established its own processing plant in 1994. The Bolivian producers' Cooperativa Integral Agroextractivista Campesinos de Pando (COINACAPA), formed in 2001, adopted the innovative strategy of contracting third-party processing plants, which allowed the cooperative to sell shelled nuts to international buyers and thus capture a greater share of value for members without the risk and overhead costs associated with managing an industrial plant themselves (Cronkleton and Albornoz 2009). Some governments have directly supported producer organizations, as can be seen with the government-

\footnotetext{
${ }^{1}$ FAOSTAT lists Cote d'Ivoire as the source of $15 \%$ of the global Brazil nut production in 2013 making it the fourth largest producer (on top of Perú). As Bertholletia excelsa is a strictly Amazonian tree species we believe this is an error and suspect FAOSTAT refers, in the case of Cote d'Ivoire, to cashew nuts.
} 
run Cooperativa Central de Comercialização Extrativista do Estado do Acre Ltda (COOPERACRE), which, since 2001, has been tied to the State of Acre's Forest Secretariat, and provides an official umbrella organization for local cooperatives across the state and serves as a market outlet for thousands of Brazil nut harvesters (Silva 2010). Although the growth of these cooperatives has been fundamental for linking Brazil nut harvesters to global markets, Peruvian harvesters on the contrary largely suffer from lack of social cohesiveness and knowledge exchange among various produceŕs associations thus hampering progress toward equity and enhanced market access (Quaedvlieg et al. 2014). And, as for most Amazonian rural populations (Mathews and Schmink 2015), informal financing in the Brazil nut sector is the norm since access to formal microcredit is largely nonexistent (Cronkleton and Pacheco 2010; Perales and Guariguata 2015) as well as for Amazonian smallholder forestry operations as a whole (Pacheco et al. 2016).

A related innovation in the Brazil nut supply chain came with the emergence of three certification schemes: (i) organic certification; (ii) Fairtrade certification; and (iii) Forest Stewardship Council (FSC) certification (Duchelle et al. 2014b). Organic certification has been the most relevant and useful. Since Brazil nuts are a wild product, production is essentially organic, so standards focus primarily on post-harvest handling (to ensure they do not become contaminated with aflatoxins while in storage, or with petrochemical pesticides during transport). Fairtrade certification, which requires producers to be organized in cooperatives and verify that they are small producers, not intermediaries, provides access to niche markets offering price premiums. However, the most important advantage that Fairtrade arrangements offer is that small producer groups are able to sell directly to buyers in foreign markets.

There are multiple benefits of these individual certification schemes (and combinations thereof). Among Brazil nut producers in southwestern Amazonia, a combination of organic and Fairtrade certification was associated with better post-harvest practices and higher prices, while FSC certification was related to pre-harvest planning (Duchelle et al. 2014b). Of the three above mentioned schemes, organic certification has gained the most traction due in part to European Union legislation that tolerates only limited amounts of fungusproduced aflatoxins (up to 10 parts per billion) in imported Brazil nuts. Since the fungus thrives when nuts remain on the forest floor for extended periods of time (Hudler 1998), Brazil nut producers are encouraged to dry nuts post-harvest to avoid contamination. The construction of drying structures became part of a series of 'best management practices' outlined in the extension literature (Cardó 2000; Wadt et al. 2005; APIZ 2008). While FSC standards for Brazil nuts have been developed in Brazil, Peru and Bolivia, there are few experiences of FSC certification on the ground, since it is perceived as costly as it attempts to cover too many forest management dimensions for what is considered a non-destructive harvesting activity (Duchelle et al. 2014b).

\section{The resource system}

Relatively high Brazil nut prices over the past decade have generated incentives for gatherers to defend the Brazil nut resource system; however, there are continued threats to these resources and a need for more government attention to support forest conservation. For example, new economic opportunities for forest-dependent people are inducing a transition from traditional extractive activities to greater investment in cattle ranching (Salisbury and Schmink 2007; Gomes 2009; Coomes et al. 2016). In addition, trans- 
boundary road connectivity through the southwestern Amazon, although relatively recent, is already leading to forest conversion in this key Brazil nut-producing region (Southworth et al. 2011; Perz et al. 2013). Moreover, market fluctuations in Brazil nut prices (which remove incentives for producers to maintain production) and policy failures (such as when governments do not defend extractivist property rights or introduce regulations that undercut harvesters; e.g., Perales and Guariguata 2015), are worrisome. In addition, the social implications for the permanence of the resource system due to an aging extractivist population are not insubstantial, especially when the many harvesters are elderly, as is the case in Madre de Dios, Peru. Likewise, and in spite of earlier concerns regarding the lack of the regenerative potential of Brazil nut-rich forests in some locations across the Amazon basin due to fruit overharvesting (Peres et al. 2003), which can be tackled by adaptive management, these seem small compared with the threats of deforestation on the continued provision of Brazil nuts. We discuss below what we consider key strategic entry points that could help to maintain the resource base over the long term.

\section{Understanding livelihood strategies and drivers of population exodus}

Remote sensing studies suggest that at present, Brazil nut-rich forests can be robust to conversion to non-forest uses such as in southwestern Amazonia (Perz et al. 2013). However, on-the-ground assessments indicate that forest permanence is contingent on a variety of current and historical factors that generate particular livelihood outcomes. In locations where access to main roads and infrastructure development is limited and opportunities for livelihood diversification remain constrained, a higher degree of forest cover at the household level is linked to a high economic dependency on the Brazil nut harvest (Zenteno et al. 2013; Duchelle et al. 2014a; Zeidemann et al. 2014; Soriano et al. 2017). When household economies start to diversify through the acquisition of more material assets, income from Brazil nut sales are typically reinvested into non-forest activities (Duchelle et al. 2014a). Thus, the 'cornerstone' role of the Brazil nut in forest conservation seems contingent on a unique livelihood strategy, which may not necessarily be the most profitable (Zenteno et al. 2013) nor permanent in a changing landscape. Yet in Brazil, smallholders living in extractive reserves rely on both Brazil nut harvesting as well as on non-forest uses while maintaining forest cover in settings where deforestation pressure can be high (Duchelle et al. 2014a). Importantly, even within these reserves, household characteristics such as age, amount of accumulated forest knowledge and proximity to the resource influence the overall reliance on Brazil nuts as a proportion of total cash income (Zeidemann et al. 2014).

Based on the above, and as recently demonstrated by Zenteno et al. (2013) and Soriano et al. (2017) in Bolivia, and Scullion et al. (2016) in Peru, explicit consideration of differentiated local livelihood strategies and resource use perspectives are essential for designing specific interventions to conserve the Brazil nut resource system while meeting development needs. For example, smallholders protect their forest fallows from further conversion when they detect a sufficient number of Brazil nut trees worth keeping (Paiva et al. 2011). Specific considerations that promote secondary forest conservation-throughuse may help to achieve this end. In particular, recognizing that secondary forests serve both agricultural and environmental functions is key for fostering inclusive policies that incorporate the views of production and conservation actors (Vieira et al. 2014, Chazdon and Guariguata 2016) while moving away from technocratic forest management approaches applied to this particular forest resource (Cronkleton et al. 2013). In addition, understanding the drivers of rural-to-urban migration can help in the design of effective 
policies and incentive structures. The decline in rubber prices played a major, historical role in promoting migration from forests into cities in Amazonia (see Parry et al. 2010). Recently, migration from remote areas (once almost entirely dependent on forest extractivism) to local urban centers in the Brazilian state of Amazonas appears to have been primarily driven by lack of access to education (Parry et al. 2010). Thus, providing educational facilities as well as other key services and programs could help motivate people to stay in forested areas.

Hunting becomes the main source of protein during the Brazil nut harvest season particularly in locations away from permanent settlements (Rumiz and Maglianesi 2001). Besides promoting local depletion of vertebrate fauna, exacerbated hunting pressure limits the dispersal of mammal-consumed tree seeds of commercial importance (Forget and Jansen 2007), including the Brazil nut tree (Haugaasen et al. 2012). Vertebrate defaunation also impairs tree regeneration which may lead to loss of aboveground forest biomass as evidenced in Amazonia (Peres et al. 2016). In Peru, hunting is prohibited by law in Brazil nut concessions (SERFOR 2016) and in Bolivia, hunting is also legally banned countrywide although particular species can be hunted for subsistence (Gaceta Oficial de Bolivia, Decreto Supremo nos. 22641 and 25458). Yet because of the (often) remote nature of Brazil nut harvesting, enforcement and monitoring is virtually impossible. As most Amazon basin countries lack clear policy frameworks for allowing subsistence consumption of bushmeat by rural populations (see e.g. van Vliet et al. 2015), designing participatory schemes for promoting sustainable hunting are warranted (e.g. Sandrin et al. 2016).

\section{Curbing deforestation}

The collapse of the Brazil nut sector in the eastern Brazilian Amazon from its peak in the 1950s can provide policy lessons on what to avoid in promoting sustainability in other parts of the Amazon basin. The construction of multiple highways and dams in the region, national support for mining projects, and the conflictual land occupation that followed, all contributed to the massive devastation of Brazil nut-rich forests along with a major decline in Brazil nut production at the national level (Homma 2001; Coslovsky 2014). Thus, key to promoting the long-term sustainability of Brazil nut-rich forests are domestic efforts to curb deforestation. Brazil and Peru have both included measures to reduce deforestation and forest degradation in their Nationally Determined Contributions (NDCs) toward keeping the global temperature rise below $2.0^{\circ} \mathrm{C}$. Furthermore, subnational government members of the Governors' Climate and Forests (GCF) Task Force have pledged to reduce deforestation in their states and provinces by $80 \%$ by 2020 through the Rio Branco Declaration (GCF 2014). The members of the GCF include the Brazil nut-producing states of Acre, Amapá, Amazonas, Maranhão, Mato Grosso, Pará, Rondônia in Brazil, along with the department of Madre de Dios in Peru. Brazil's success in reducing Amazonian deforestation (INPE 2015) is largely attributed to increased regulatory efforts, including monitoring and enforcement by the Brazilian Institute of Environment (IBAMA), along with a slowdown in the growth of commodity prices that curbed investments in forest clearing (Assunção et al. 2012). Yet, such trends are not sustainable if protection measures are weakened and landholders do not receive incentives for conserving forests, as seen from the recent increase in deforestation in the Brazilian Amazon (Tollefson 2016). Identifying the main drivers of deforestation within Brazil nut-rich forests in local and/or subnational contexts is also necessary to inform decision-makers on sound policy and practical alternatives. For example, in Brazil nut-rich forests of Pando, Bolivia, cattle- 
ranching is currently the main driver of deforestation (Müller et al. 2013), while in Madre de Dios, Peru, illegal yet highly profitable gold mining is steadily encroaching into Brazil nut concessions (Scullion et al. 2014). To the extent that forest and agricultural policies are harmonized, integrated production systems are promoted, and cross sectorial land use planning is effectively implemented, deforestation pressures can be minimized.

The designation of extractive reserves and indigenous reserves, such as through Brazil's Amazon Protected Areas Program, can have positive implications for the Brazil nut socioecological system. These areas have played a fundamental role in mitigating deforestation (Nepstad et al. 2006; Pfaff et al. 2014), and many shelter Brazil nut-rich forests and human populations that partially depend on this species for their livelihoods. Opportunities exist to bolster conservation of Brazil nut-rich forests through incentives associated with Reducing Emissions from Deforestation and Forest Degradation (REDD+). In Peru, Brazil nut concessions store, as a land use type, the largest aboveground carbon densities across the country (110 $\mathrm{Mg} \mathrm{C}^{-1}$; Asner et al. 2014). And basinwide, Brazil nut trees rank third among the dominant top 20 tree species in terms of aboveground biomass (Fauset et al. 2015) while being an "hyperdominant" element of the tree flora (ter Steege et al. 2013). At the national level, Perús National Forest Conservation Program (http://www.bosques.gob.pe/grants) grants subsidies per hectare to native and indigenous communities holding large tracts of forest in exchange for avoiding deforestation and degradation (Börner et al. 2016). This intervention could be emulated in the country's Brazil nut concessions.

There are also nearly 80 subnational REDD+ programs and projects throughout the Amazon (Simonet et al. 2015), including one that focuses specifically on Brazil nut producers. The REDD+ project in Brazil nut concessions in Madre de Dios, Peru, is a contractual partnership between the company Bosques Amazonicos (BAM) and the local federation of nut producers. BAM provides financial and technical support to Brazil nut concessionaires, including a share of profits from carbon offset sales on the voluntary market and access to a local nut processing plant to enhance the product́s value, in exchange for forest carbon rights (Garrish et al. 2014). Despite the potential for REDD+ to bolster income gleaned from Brazil nuts in Madre de Dios (Nunes et al. 2012), challenges do exist. For example, in Bolivia, the titled areas for Brazil nut communities are frequently irregularly shaped, noncontiguous, and do not include all stands claimed by the community, which makes the resources difficult for residents to defend (Cronkleton et al. 2009). In Peru, lack of coordination between governmental agencies has resulted in overlapping property rights and land allocation in areas set aside for Brazil nut concessions (Chavez et al. 2012). Yet there is hope, as Norway and Germany's recent USD 240 million pledge to Peru for REDD+ (https://www.regjeringen.no/contentassets/b324ccc0cf88419fab88f2f4c7101f20/ declarationofintentperu.pdf) includes, for example, regularization of indigenous lands, along with assigning undesignated forestland to indigenous areas, protected areas, and timber and non-timber production areas.

\section{Promoting integrated management approaches and sustainable value chains}

Multiple use forest management, while riddled at times with acute development and ecological trade-offs (García-Fernández et al. 2008; Guariguata et al. 2010), has the potential to generate a financial edge over mono-productive options (Ashton et al. 2001; Wang and Wilson 2007). In Peru, harvesting of Brazil nut is both a financially attractive and complementary activity in ecotourism forest concessions (Kirby et al. 2010) and biophysically compatible with low intensity timber harvesting (Rockwell et al. 2015). Across its vast 
geographical range, the Brazil nut tree coexists with dozens of timber species (ter Steege et al. 2013; Fauset et al. 2015). And although integrated timber-Brazil nut management can be hampered due to policy, economic and technical constraints (Guariguata et al. 2009; Cronkleton et al. 2012b; Duchelle et al. 2012; Rockwell et al. 2015), many of these tradeoffs are not insurmountable. To this end, such integrated management approaches need further development from a technical, regulatory and educational standpoint (Guariguata et al. 2012). In addition to timber regulations, Brazil nut harvesters in Peru, for example, are separately mandated to comply with complex procedures for harvesting, transporting and selling the nuts (Perales and Guariguata 2015) from within the same forest location. That said, Bolivia's success in dominating the global Brazil nut export market (Coslovsky 2014) has relied less on harvesters following government-led regulations and norms, and more on adapting to international market and trade forces.

Minimizing international price volatility in Brazil nuts is also warranted since a few factors interact in generating price fluctuations. First, "good" and "bad" export years are the combined outcome of inter-annual variation in tree fecundity (Kainer et al. 2007; Rockwell et al. 2015), coupled to weather events such as extended dry seasons that impair river transport and/or floods that damage largely unpaved roads, hindering both access to, and exit from, the forest. Second, because Brazil nuts travel large trans-oceanic distances from producer to importing countries, shipment delays are unavoidable thus affecting the size and storage quality of Brazil nut stocks and therefore the capacity of suppliers and buyers to satisfy demand at any given time. Positive feedbacks can also play a role since low motivation for harvesters to enter the forest in a given year may arise due to low prices the preceding year. Fourth, Brazil nut prices are known to shift as a function of other internationally traded nuts. In addition, the Brazil nut market is subject to heavy speculation since future prices are not negotiated in advance. Hence, state-led and private sector interventions may need to be adapted to locally relevant market approaches and value chains from traditional Amazonian extractivists to global commodity markets (Pokorny and Pacheco 2014). Evidence from Brazil and Bolivia highlights how partnerships between local communities and companies in NTFP commercialization may enhance their wellbeing (Morsello et al. 2012). Increasing national and international consumer awareness is also key. Although Brazil nuts are a well-known export NTFP for decades, broadening their use by showcasing the nutritional and health benefits is paramount for improving supply chain value and helping to buffer price fluctuations. Brazil nuts are a natural source of selenium (Chang et al. 1995), a mineral with antioxidant properties. They are also a good source of (unsaturated) fatty acids that help reduce coronary heart disease, while also being an alternative for those with gluten intolerance (Yang 2009). The Brazilian national market has a wider array of finished products derived from Brazil nuts (Homma et al. 2014), compared to Peru and Bolivia both of which export most of the shelled and unshelled nuts they produce (although incipient product diversification is emerging). This is probably because the market share of Brazil's production is larger internal than externally (74 vs. $26 \%$, respectively; Toledo et al. 2016).

\section{Conclusions}

Returning to our organizing framework, we find through this review that the resource unit (i.e., the Brazil nut tree) reacts robustly to the type and level of extraction currently practiced. Its longevity buffers the impact of repeated harvesting episodes on population 
regeneration (Zuidema and Boot 2002; Brienen and Zuidema 2006). Likewise, the diverse resource users have developed a self-organized system that allocates access to the resource base, links to, and supplies global markets, and provides informal financing. Further, resource users have developed endogenous management systems that do not require major change to sustain productivity. In addition, the governance system has, either formally or informally, been supportive to Brazil nut gatherers and the sector as a whole. Yet as more roads dissect Amazonian forests and income from agricultural expansion in the Amazon region transforms local economies, the extraction of forest products may eventually play a lesser role (Ruiz-Pérez et al. 2004; Coomes et al. 2016). Since long-term Brazil nut production seems inextricably tied to a continuous forest cover, one key intervention is clearly to preserve large expanses of productive Brazil nut-rich forests functionally integrated within human-modified landscapes (Sayer et al. 2013; Reed et al. 2016).

Efforts may also be needed to enrich forests in a cost-effective manner to enhance the abundance of pre-reproductive Brazil nut trees. For example, despite the fact that in Peru many Brazil nut concessionaires extract timber as supplementary income (Garrish et al. 2014), historical harvesting intensities have been insufficient in opening up the canopy to the point of significantly enhancing natural regeneration of Brazil nut trees which average only one pre-reproductive individual (10-40 cm in diameter) per every 10 ha (Rockwell et al. 2017). And although timber will keep providing a substantial proportion of forestbased income in Brazil nut-rich forests (Zenteno et al. 2013; Garrish et al. 2014), there is still a notable lack of technical support for managing Brazil nut-timber systems, incorporating local knowledge, focusing less on top-down regulations and more on promoting good practice (Cronkleton et al. 2012b; Duchelle et al. 2012). To this end, the design and implementation of flexible and integrated frameworks adapted to the realities of smallholders, along with suitable extension and financial services are paramount. Peru seems to rely more on command-and-control policies and regulations for smallholder forestry compared, for example, to Bolivia (Pacheco et al. 2016).

Fostering dialogue between different stakeholders-including buyers at the very end of the value chain in developed countries - is also paramount for enhancing equity and benefit sharing. Taking a broader view, it is important to note that certification organizations, such as the FSC, are rethinking their hitherto timber-oriented philosophy and moving to holistic and cross-sectorial approaches that incorporate forest-based ecosystem goods and services (FSC 2015). Expanding Brazil nut harvesting into a "good practice" landscape approach that explicitly includes other ecosystem services and biodiversity conservation benefits could potentially be achieved in the future (Tscharntke et al. 2014). Explicit integration and recognition of Brazil nut harvesting into other productive activities that are also usually carried out by extractivists, such as farming and hunting (as mentioned above), will be needed.

Finally, while granting property rights has been a very important benefit that goes a long way towards maintaining the resource system, national and local governments still need to monitor who continues to hold these rights and ensure the involvement of smallholder extractivists. It is also critical for governments to make sure that devolved rights to Brazil nut harvesters are not transferred to third parties intent on forest conversion. Our own experience in the region suggests that, at present, governments are not doing enough to monitor what happens to Brazil nut harvesters' rights once they are granted. As described here, the overall resource system does face threats, and continued follow up is needed to support all the key four components described in this paper so they can be adapted to interact in a positive manner in rapidly changing conditions. And as shown above, the role of Brazil nut as the cornerstone of Amazon forest conservation is at present highly 
contextual and modulated by both internal and external factors. Tailored interventions that are adapted to the local context may contribute to maintaining the resource base in the long-term.

Acknowledgements This work was funded by the CGIAR Program on Forests, Trees and Agroforestry and by the KNOWFOR program from the United Kingdoms Department for International Development. M.R. Guariguata received support during initial manuscript preparation from an Erasmus Mundus European Forestry Scholar Grant. A. Almeyda, O. Coomes, and C. Rockwell provided useful comments into earlier drafts. We also appreciate the inputs from Marco Antonio Albornoz, Damian Rumiz, and Flora Ferreira Camargo. And we thank two anonymous reviewers for their critical comments and observations which greatly helped to improve the manuscript.

Open Access This article is distributed under the terms of the Creative Commons Attribution 4.0 International License (http://creativecommons.org/licenses/by/4.0/), which permits unrestricted use, distribution, and reproduction in any medium, provided you give appropriate credit to the original author(s) and the source, provide a link to the Creative Commons license, and indicate if changes were made.

\section{References}

Allegretti M (1990) Extractive reserves: an alternative for reconciling development and environmental conservation in Amazonia. In: Anderson AB (ed) Alternatives to deforestation: steps toward sustainable use of the Amazon rainforest. Columbia University Press, New York, pp 252-264

Angelsen A, Jagger P, Babigumira R et al (2014) Environmental income and rural livelihoods: a global comparative analysis. World Dev 74:512-528

Ankersen T, Barnes G (2004) Inside the polygon: emerging community tenure systems and forest resource extraction. In: Zarin DJ, Alavalapati JRR, Putz FE, Schmink M (eds) Working forests in the neotropics: conservation through sustainable management?. Columbia University Press, New York, pp 156-177

APIZ (Associação do Povo Indígena Zoró) (2008) Boas práticas de coleta, armazenamento e comercialização da castanha-do-Brasil: Capacitação e intercâmbio de experiências entre os povos da Amazônia mato-grossense com manejo de produtos florestais não-madeireiros. Defianti Editora, Cuiabá

Ashton MS, Mendelsohn R, Singhakurama BMP, Gunatilleke CVS, Gunatilleke IAUN, Evans A (2001) A financial analysis of rain forest silviculture in southwestern Sri Lanka. For Ecol Manag 154:431-441

Asner GP, Knapp DE, Martin RE et al (2014) Targeted carbon conservation at national scales with highresolution monitoring. Proc Natl Acad Sci USA 111:E5016-E5022

Assies W (1997a) Going nuts from the rainforest: Non-timber Forest Products, forest conservation and sustainability in Amazonia. Thela Publishers, Amsterdam

Assies W (1997b) The extraction of non-timber forest products as a conservation strategy in Amazonia. Rev Eur Estud Latinoam Caribe 62:33-52

Assunção J, Gandour CC, Rocha R (2012) Deforestation slowdown in the Legal Amazon: prices or policies?. Climate Policy Initiative/PUC Rio, Rio de Janeiro

Bakx K (1988) From proletarian to peasant: rural transformation in the state of Acre, 1870-1986. J Dev Stud 24:141-160

Barham BL, Coomes OT (1996) Prosperity's promise: the Amazon rubber boom and distorted economic development. Dellplain Latin American Studies Series. Westview Press, Boulder

Belcher B, Ruiz-Pérez M, Achdiawan R (2005) Global patterns and trends in the use and management of commercial NTFPs: implications for livelihoods and conservation. World Dev 33:1435-1452

Börner J, Wunder S, Giudice R (2016) Will up-scaled forest conservation incentives in the Peruvian Amazon produce cost-effective and equitable outcomes? Environ Conserv 43:407-416

Brienen RJW, Zuidema PA (2006) Lifetime growth patterns and ages of Bolivian rain forest trees obtained by tree ring analysis. J Ecol 94:481-493

Cardó AA (2000) Manejando bien tu castañal. Asociación para la Conservación de la Cuenca Amazónica (ACCA), Puerto Maldonado

Cavalcante MC, Oliveira FF, Maués MM, Freitas BM (2012) Pollination requirements and the foraging behavior of potential pollinators of cultivated Brazil nut (Bertholletia excelsa Bonpl.) trees in Central Amazon rainforest. Psyche doi:10.1155/2012/978019

Chang JC, Gutenmann WH, Reid CM, Lisk DJ (1995) Selenium content of Brazil nuts from two geographic locations in Brazil. Chemosphere 30:801-802 
Chavez A, Guariguata MR, Cronkleton P, Menton M, Capella JL, Araujo JP, Quaedvlieg J (2012) Superposición espacial en la zonificación de bosques en Madre de Dios. CIFOR Infobrief no. 58, Center for International Forestry Research, Bogor

Chazdon RL, Guariguata MR (2016) Natural regeneration as a tool for large-scale forest restoration in the tropics: prospects and challenges. Biotropica 48:716-730

Clay JW (1997) Brazil nuts. The use of a keystone species for conservation and development. In: Freese CR (ed) Harvesting wild species: implications for biodiversity conservation. John Hopkins University Press, Baltimore, pp 246-282

Clay JW, Clement CR (1993) Selected species and strategies to enhance income generation from Amazonian forests. FAO miscellaneous paper 93/6. Food and Agriculture Organization of the United Nations, Rome

Clement CR, Denevan WM, Heckenberger MJ, Junqueira AB, Neves EG, Teixeira WG, Woods WI (2015) The domestication of Amazonia before European conquest. Proc R Soc B 282:20150813

Congreso del Perú (2002) Forum "La Castaña Peruana, Producto Ecologico para el Mundo". http://www4. congreso.gob.pe/congresista/2001/esalhuana/Eventos/castana_new.htm. Accessed 20 Sept 2016

Coomes OT, Barham BL (1994) The Amazon rubber boom: labor control, resistance, and failed plantation development revisited. Hisp Am Hist Rev 74:231-257

Coomes O, Takasaki Y, Abizaid C, Arroyo-Mora P (2016) Environmental and market determinants of economic orientation among rain forest communities: evidence from a large scale survey in western Amazonia. Ecol Econ 129:260-271

Coslovsky SV (2014) Economic development without pre-requisites: how Bolivian producers met strict food safety standards and dominated the global Brazil-nut market. World Dev 54:32-45

Cossio-Solano RE, Guariguata MR, Menton M, Capella JL, Rios L, Peña P (2011) El aprovechamiento de madera en las concesiones castañeras (Bertholletia excelsa) en Madre de Dios, Perú: un análisis de su situación normativa. Documento de Trabajo 56. Center for International Forestry Research (CIFOR), Bogor

Cotta JN, Kainer KA, Wadt LHO, Staudhammer CL (2008) Shifting cultivation effects on Brazil nut (Bertholletia excelsa) regeneration. For Ecol Manag 256:28-35

Cronkleton P, Albornoz MA (2009) Acción colectiva y mercados alternativos para la castaña: análisis comparativo de tres cooperativas en el norte amazónico de Bolivia. Center for International Forestry Research (CIFOR) and Centro de Estudios para el Desarrollo Laboral y Agrario (CEDLA), La Paz

Cronkleton P, Pacheco P (2010) Changing policy trends in the emergence of Bolivia's Brazil nut sector. In: Laird SA, McLain R, Wynberg R (eds) Wild product governance: finding policies that work for nontimber forest products. Earthscan, London, pp 15-42

Cronkleton P, Taylor P, Barry D, Stone-Jovicich S, Schmink M (2008) Environmental governance and the emergence of forest-based social movements. CIFOR Occasional Paper 49. Center for International Forestry Research (CIFOR), Bogor

Cronkleton P, Pacheco P, Ibarguen R, Albornoz MA (2009) Reformas en la tenencia de la tierra y los bosques: La gestión comunal en las tierras bajas de Bolivia. Center for International Forestry Research (CIFOR) and Centro de Estudios para el Desarrollo Laboral y Agrario (CEDLA), La Paz

Cronkleton P, Albornoz MA, Evans K, Barnes G, de Jong W (2010) Social geomatics: participatory forest mapping to mediate resource conflict in the Bolivian Amazon. Hum Ecol 38:65-76

Cronkleton P, Pulhin JM, Saigal S (2012a) Co-management in community forestry: how the partial devolution of management rights creates challenges for forest communities. Conserv Soc 10:91-102

Cronkleton P, Guariguata MR, Albornoz MA (2012b) Multiple use forestry planning: timber and Brazil nut management in the community forests of Northern Bolivia. For Ecol Manag 268:49-56

Cronkleton P, Larson AM, Feintrenie L, García C, Levang P (2013) Reframing community forestry to manage the forest-farm interface. Small Scale For 12:5-13

de Jong W, Borner J, Pacheco P, et al. (2010) Amazon forests at the crossroads: pressures, responses and challenges. In: Mery G, Katila P, Galloway G, et al. (eds) Forests and society: responding to global drivers of change. IUFRO World Series 25. IUFRO, Vienna, pp 283-298

de Salomão RP (1991) Estrutura e densidade de Bertholletia excelsa H. \& B. ("castanheira") nas regiões de Carajás e Marabá, Estado do Pará. Bol. Museu Par. Emílio Goeldi sér. bot. 7:47-68

Duchelle A, Cronkleton P, Kainer KA, Guanacoma G, Gezan S (2011) Resource theft in tropical forest communities: implications for non-timber management, livelihoods, and conservation. Ecol Soc 16(1):4

Duchelle AE, Guariguata MR, Less G, Albornoz MA, Chávez A (2012) Evaluating the opportunities and limitations to multiple use of Brazil nuts and timber in Western Amazonia. For Ecol Manag 268:39-48

Duchelle AE, Almeyda Zambrano AM, Wunder S, Börner J, Kainer KA (2014a) Smallholder specialization strategies along the forest transition curve in Southwestern Amazonia. World Dev 64:S149-S158 
Duchelle AE, Kainer KA, Wadt LHO (2014b) Is certification associated with better forest management and socioeconomic benefits? A comparative analysis of three certification schemes applied to Brazil nuts in Western Amazonia. Soc Nat Resour 27:121-139

Fauset S, Johnson M, Gloor M et al (2015) Hyperdominance in Amazonian forest carbon cycling. Nat Commun 6:6857

Fifer JV (1970) The empire builders: a history of the Bolivian rubber boom and the rise of the house of Suárez. J Lat Am Stud 2:113-146

Forget P-M, Jansen PA (2007) Hunting increases dispersal limitation in the tree Carapa procera, a nontimber forest product. Conserv Biol 21:106-113

Fortmann L (1985) The tree tenure factor in agroforestry with particular reference to Africa. Agrofor Syst 2:229-251

FSC (2015) Forest Stewardship Council Global Strategic Plan 2015-2020. https://ic.fsc.org/en/about-fsc/ fsc-global-strategic-plan-2015-2020. Accessed 20 Sept 2016

García-Fernández C, Ruiz Pérez M, Wunder S (2008) Is multiple-use forest management widely implementable in the tropics? For Ecol Manag 256:1468-1476

Garrish V, Perales E, Duchelle AE, Cronkleton P (2014) The REDD Project in Brazil nut concessions in Madre de Dios, Peru. In: Sills EO, Atmadja SS, de Sassi C, Duchelle AE, Kweka DL, Resosudarno IAP, Sunderlin WD (eds) REDD+ on the ground. Center for International Forestry Research (CIFOR), Bogor, pp 147-165

GCF (2014) Rio Branco Declaration: Building partnerships and securing support for forests, climate and livelihoods. Rio Branco. http://www.gcftaskforce.org/documents/2014_annual_meeting/GCF_ RioBrancoDeclaration_August_5_2014_EN.pdf

Gomes CVA (2009) Twenty years after Chico Mendes: Extractive Reserves' expansion, cattle adoption and evolving self-definition among rubber tappers in the Brazilian Amazon. Ph.D. Dissertation. University of Florida, Gainesville, Florida

Guariguata MR, Licona JC, Mostacedo B, Cronkleton P (2009) Damage to Brazil nut trees (Bertholletia excelsa) during selective timber harvesting in Northern Bolivia. For Ecol Manag 258:788-793

Guariguata MR, García-Fernández C, Sheil D et al (2010) Compatibility of timber and non-timber forest product management in natural tropical forests: perspectives, challenges and opportunities. For Ecol Manag 259:237-245

Guariguata MR, Sist P, Nasi R (2012) Multiple use management of tropical production forests: how can we move from concept to reality? For Ecol Manag 268:1-5

Haugaasen JMT, Haugaasen T, Peres CA, Gribel R, Wegge P (2012) Fruit removal and natural seed dispersal of the Brazil nut tree (Bertholletia excelsa) in Central Amazonia, Brazil. Biotropica 44:205-210

Homma AKO (2001) As políticas públicas como indutora da "morte anunciada" dos castanhais no sudeste paraense. Anais do Encontro Nacional da Sociedade Brasileira de Economia Ecológica 4. Belém, Pará

Homma AKO, Menezes AJEA, Maués MM (2014) Castanheira-do-pará: os desafios do extrativismo para plantios agrícolas. Boletim do Museu Paraense Emilio Goeldi. Ciências Naturais 9:293-306

Hudler GW (1998) Magical mushrooms, mischievous molds: the remarkable story of the fungus kingdom and its impact on human affairs. Princeton University Press, Princeton

INPE (Instituto Nacional de Pesquisas Espaciais) (2015) Projeto PRODES: monitoramento da floresta Amazônica brasileira por satélite. São José dos Campos

Kainer KA, Wadt LHO, Staudhammer CL (2007) Explaining variation in Brazil nut fruit production. For Ecol Manag 250:244-255

Kirby CA, Giudice-Granados R, Day B et al (2010) The market triumph of ecotourism: an economic investigation of the private and social benefits of competing land uses in the Peruvian Amazon. PLoS ONE 5(9):e13015

Kusters K, Achdiawan R, Belcher B, Ruiz-Pérez M (2006) Balancing development and conservation? An assessment of livelihood and environmental outcomes of nontimber forest product trade in Asia, Africa, and Latin America. Ecol Soc 11(2):20

Laird SA, McLain R, Wynberg RP (eds) (2010) Wild product governance: finding policies that work for non-timber forest products. Earthscan, London

Lawrence A (2003) No forest without timber? Int For Rev 5:87-96

Mathews MC, Schmink M (2015) "Differentiated citizenship" and the persistence of informal rural credit systems in Amazonia. Geoforum 65:266-277

MDS (1998). Normas técnicas para la elaboración de instrumentos de manejo forestal en propiedades privadas o concesiones con superficies mayores a 200 hectáreas. Res. Min. No. 248/98. Ministerio de Desarrollo Sostenible y Medio Ambiente, La Paz 
MDS (2005) Norma técnica para elaboración de planes de manejo de castaña (Bertholletia excelsa Humb \& Bonpl.). Resolución Ministerial N 077/2005. Ministerio de Desarrollo Sostenible Viceministerio de Recursos Naturales y Medio Ambiente, La Paz

Mori SA, Prance GT (1990) Taxonomy, ecology, and economic botany of the Brazil nut (Bertholletia excelsa Humb. and Bonpl: Lecythidaceae). Adv Econ Bot 8:130-150

Morsello C, Ruiz-Mallén I, Diaz MDM, Reyes-García V (2012) The effects of processing non-timber forest products and trade partnerships on people's well-being and forest conservation in Amazonian societies. PLoS ONE 7(8):e43055

Müller R, Pistorius T, Rohde S, Gerold G, Pacheco P (2013) Policy options to reduce deforestation based on a systematic analysis of drivers and agents in lowland Bolivia. Land Use Policy 30:895-907

Myers GP, Newton AC, Melgarejo O (2000) The influence of canopy gap size on natural regeneration of Brazil nut (Bertholletia excelsa) in Bolivia. For Ecol Manag 127:119-128

Nepstad D, Schwartzman S, Bamberger B et al (2006) Inhibition of Amazon deforestation and fire by parks and indigenous lands. Conserv Biol 20:65-73

Newing H, Harrop S (2000) European health regulations and Brazil nuts: implications for biodiversity conservation and sustainable rural livelihoods in the Amazon. J Int Wildl Law Policy 3:109-124

Newton AC (2008) Conservation of tree species through sustainable use: how can it be achieved in practice? Oryx 42:195-205

Nunes F, Soares-Filho B, Giudice R et al (2012) Economic benefits of forest conservation: assessing the potential rents from Brazil nut concessions in Madre de Dios, Peru, to channel REDD+ investments. Environ Conserv 39:132-143

Ormachea E, Fernández J (1989) Amazonia boliviana y campesinado. Cooperativa Integral Campesino, Riberalta

Ortiz E (2002) Brazil nut (Bertholletia excelsa). In: Shanley P, Pierce AR, Laird SA, Guillen A (eds) Tapping the green market: certification and management of non-timber forest products. Earthscan, London, pp 61-74

Ostrom E (1990) Governing the commons. Cambridge University Press, New York

Ostrom E (2009) A general framework for analyzing sustainability of social-ecological systems. Science 325:419-422

Pacheco P (1992) Integración económica y fragmentación social: el itinerario de las barracas en la Amazonia Boliviana. Centro de Estudios para el Desarrollo Laboral y Agrario (CEDLA), La Paz

Pacheco P (1998) Pando: barraqueros, madereros y conflictos por el uso de los recursos forestales. In: Pacheco P, Kaimowitz D (eds) Municipios y Gestión Forestal en el Trópico Boliviano. CIFOR/ CEDLA/TIERRA/BOLFOR. CID/Plural Editores, Bolivia, pp 179-226

Pacheco P, Mejía E, Cano W, de Jong W (2016) Smallholder forestry in the Western Amazon: outcomes from forest reforms and emerging policy perspectives. Forests 7:193

Paiva MP, Carneiro Guedes M, Funi C (2011) Brazil nut conservation through shifting cultivation. For Ecol Manag 261:508-514

Parry L, Day B, Amaral S, Peres CA (2010) Drivers of rural exodus from Amazonian headwaters. Popul Environ 32:137-176

Peña P (2010) La castaña y la shiringa en Madre de Dios: análisis del marco legal y propuestas participativas para su mejora. Sociedad Peruana de Derecho Ambiental, Lima, p 56p

Perales E, Guariguata MR (2015) Qué dicen los números? Consideraciones para una simplificación normativa del aprovechamiento y transporte de la castaña en Madre de Dios. InfoBrief 117. Center for International Forestry Research (CIFOR), Bogor

Peres CA, Baider C (1997) Seed dispersal, spatial distribution and population structure of Brazil nut trees (Bertholletia excelsa) in southeastern Amazonia. J Trop Ecol 13:595-616

Peres CA, Baider C, Zuidema PA et al (2003) Demographic threats to the sustainability of Brazil nut exploitation. Science 302:2112-2114

Peres CA, Emilio T, Schietti J, Desmoulière SJM, Levi T (2016) Dispersal limitation induces long-term biomass collapse in overhunted Amazonian forests. Proc Natl Acad Sci USA 113:892-897

Perz SG, Qiu Y, Xia Y et al (2013) Trans-boundary infrastructure and land cover change: highway paving and community-level deforestation in a tri-national frontier in the Amazon. Land Use Policy 34:27-41

Pfaff A, Robalino J, Lima E, Sandoval C, Herrera LD (2014) Governance, location and avoided deforestation from protected areas: greater restrictions can have lower impact, due to differences in location. World Dev 55:7-20

Pokorny B, Pacheco P (2014) Money from and for forests: a critical reflection on the feasibility of market approaches for the conservation of Amazonian forests. J Rural Stud 36:441-452

Quaedvlieg J, García Roca M, Ros-Tonen MAF (2014) Is Amazon nut certification a solution for increased smallholder empowerment in Peruvian Amazonia? J Rural Stud 33:41-55 
Reed J, Van Vianen J, Deakin E, Barlow J, Sunderland T (2016) Integrated landscape approaches to managing social and environmental issues in the tropics: learning from the past to guide the future. Glob Chang Biol 22:2540-2554

Ribeiro MBN, Jerozolimski A, de Robert P, Magnusson WE (2014) Brazil nut stock and harvesting at different spatial scales in southeastern Amazonia. For Ecol Manag 319:67-74

Rockwell CA, Guariguata MR, Menton M et al (2015) Nut production in Bertholletia excelsa across a logged forest mosaic: implications for multiple forest use. PLoS ONE 10(8):e0135464

Rockwell CA, Guariguata MR, Menton M et al (2017) Spatial distribution of Bertholletia excelsa in selectively logged forests of the Peruvian Amazon. J Trop Ecol 33:114-127

Rosendal GK (1995) The forest issue in post-UNCED international negotiations: conflicting interests and fora for reconciliation. Biodivers Conserv 4:91-107

Ruiz-Pérez M, Belcher B, Achdiawan R, Alexiades M, Aubertin C, Caballero J, Campbell B et al (2004) Markets drive the specialization strategies of forest peoples. Ecol Soc 9(2):4

Rumiz DI, Maglianesi MA (2001) Hunting impacts associated with Brazil nut harvesting in the Bolivian Amazon. Vida Silv Neotrop 10:19-29

Salisbury D, Schmink M (2007) Cows versus rubber: changing livelihoods among Amazonian extractivists. Geoforum 38:1233-1249

Sandrin F, l'Haridon L, Vanegas L, Ponta N, Gómez J, Cuellar JL, del Aguila EL, Nates J, van Vliet N (2016) Manejo comunitario de la cacería y de la fauna: avances realizados por la asociación de cazadores Airumakuchi en Puerto Nariño, Amazonas Colombia. Documento de Trabajo 213. Centro para la Investigación Forestal Internacional (CIFOR), Bogor

Sayer J, Sunderland T, Ghazoul J et al (2013) Ten principles for a landscape approach to reconciling agriculture, conservation, and other competing land uses. Proc Natl Acad Sci USA 110:8349-8356

Schmink M, Wood C (1992) Contested frontiers in Amazonia. Columbia University Press, New York

Schöngart J, Gribel R, Ferreira da Fonseca-Junior S, Haugaasen T (2015) Age and growth patterns of Brazil nut trees (Bertholletia excelsa Bonpl.) in Amazonia, Brazil. Biotropica 47:550-558

Scoles R, Gribel R (2012) The regeneration of Brazil nut trees in relation to nut harvest intensity in the Trombetas River valley of Northern Amazonia, Brazil. For Ecol Manag 265:71-81

Scoles R, Gribel R (2015) Human influence on the regeneration of the Brazil nut tree (Bertholletia excelsa Bonpl., Lecythidaceae) at Capanã Grande Lake, Manicoré, Amazonas, Brazil. Hum Ecol 43:843-854

Scullion JJ, Vogt KA, Sienkiewicz A, Gmur SJ, Trujillo C (2014) Assessing the influence of landcover change and conflicting land-use authorizations on ecosystem conversion on the forest frontier of Madre de Dios, Peru. Biol Conserv 171:247-258

Scullion JJ, Vogt KA, Winkler-Schor S, Sienkiewicz A, Peña C, Hajek F (2016) Designing conservationdevelopment policies for the forest frontier. Sustain Sci 11:295-306

SERFOR (Servicio Nacional Forestal y de Fauna Silvestre) (2016) Lineamientos para la elaboración de planes de manejo forestal intermedio para el aprovechamiento de productos forestales diferentes a la madera. Ministerio de Agricultura y Riego, Lima

SFB (Serviço Florestal Brasileiro) (2010) Plano anual de manejo florestal comunitário e familiar 2010. Serviço Florestal Brasileiro (SFB), Brasília

Shanley P, Pierce A, Laird S, López C, Guariguata MR (2016) From lifelines to livelihoods: non-timber forest products into the 21 st century. In: Pancel L, Köhl M (eds) Tropical forestry handbook. Springer, Berlin, pp 2-50

Shepard GH, Ramirez H (2011) "Made in Brazil": human dispersal of the Brazil nut (Bertholletia excelsa, Lecythidaceae) in ancient Amazonia. Econ Bot 65:44-65

Silva SMP (2010) Estado e políticas públicas no mercado de castanha-do-brasil no Estado do Acre: uma análise pela abordagem do desenvolvimento local. Revista IDeAS 4:103-128

Silva Bentes R, Marín RA, Emmi MF (1988) Os cemitérios das castanheiras do Tocantins. Pará Desenvolvimento $23: 18-23$

Simonet G, Karsenty A, Newton P, de Perthuis C, Schaap B, Seyller C (2015) REDD+ projects in 2014: an overview based on a new database and typology. Information and Debate Series No. 32. ParisDauphine University, Climate Economics Chair, Paris

Soriano M, Kainer KA, Staudhammer CL, Soriano E (2012) Implementing multiple forest management in Brazil nut-rich community forests: effects of logging on natural regeneration and forest disturbance. For Ecol Manag 268:92-102

Soriano M, Mohren F, Ascarrunz N, Dressler W, Peña-Claros M (2017) Socio-ecological costs of Amazon nut and timber production at community household forests in the Bolivian Amazon. PLoS ONE 12(2):e0170594

Southworth J, Marsik M, Qiu Y et al (2011) Roads as drivers of change: trajectories across the tri-national frontier in MAP. Remote Sens 3:1047-1066 
Stoian D, Henkemans A (2000) Between extractivism and peasant agriculture: differentiation of rural settlement in the Bolivian Amazon. Int Tree Crops J 10:299-319

Sujii PS, Martins K, Wadt LHO, Rennó Azevedo VC, Solferini VN (2015) Genetic structure of Bertholletia excelsa populations from the Amazon at different spatial scales. Conserv Genet 16:955-964

ter Steege H, Pitman NCA, Sabatier D et al (2013) Hyperdominance in the Amazonian tree flora. Science 342:1243092

Thomas E, Alcazar Caicedo C, McMichael CH, Corvera R, Loo J (2015) Uncovering spatial patterns in the natural and human history of Brazil nut (Bertholletia excelsa) across the Amazon Basin. J Biogeogr 42:1367-1382

Toledo RA, Gomes CS, Palmieri R (2016) Panorama nacional da cadeia de valor da castanha-do-Brazil. Instituto de Manejo e Certificação Florestal e Agrícola (IMAFLORA), Piracicaba, São Paulo

Tollefson J (2016) Deforestation rates spike in Brazil. Nature 540:182

Tscharntke T, Milder JC, Schroth G et al (2014) Conserving biodiversity through certification of tropical agroforestry crops and at local and landscape scales. Conserv Lett 8:14-23

van Vliet N, Gomez J, Quiceno-Mesa MP, Escobar JF, Andrade G, Venegas LA, Nasi R (2015) Sustainable wildlilfe management and legal commercial of bushmeat in Colombia: the resource remains at the cross-road. Int For Rev 17:438-447

Vieira ICG, Gardner T, Ferreira J, Lees AC, Barlow J (2014) Challenges of governing second-growth forests: a case study from the Brazilian Amazonian State of Pará. Forests 5:1737-1752

Wadt LHO, Kainer KA, Gomes-Silva DAP (2005) Population structure and nut yield of a Bertholletia excelsa stand in Southwestern Amazonia. For Ecol Manag 211:371-384

Wadt LHO, Kainer KA, Staudhammer CL, Serrano ROP (2008) Sustainable forest use in Brazilian extractive reserves: natural regeneration of Brazil nut in exploited populations. Biol Conserv 141:332-346

Wang S, Wilson B (2007) Pluralism in the economics of sustainable forest management. For Policy Econ 9:743-750

Weinstein B (1983) The Amazon rubber boom 1850-1920. Stanford University Press, Stanford

Yang J (2009) Brazil nuts and associated health benefits: a review. Food Sci Technol 42:1573-1580

Zeidemann V, Kainer KA, Staudhammer CL (2014) Heterogeneity in NTFP quality, access and management shape benefit distribution in an Amazonian extractive reserve. Environ Conserv 41:242-252

Zenteno M, Zuidema PA, de Jong W, Boot RGA (2013) Livelihood strategies and forest dependence: new insights from Bolivian forest communities. For Policy Econ 26:12-21

Zuidema PA, Boot RGA (2002) Demography of the Brazil nut tree (Bertholletia excelsa) in the Bolivian Amazon: impact of seed extraction on recruitment and population dynamics. J Trop Ecol 18:1-31 